\title{
MicroRNA and protein profiles in invasive versus non-invasive oral tongue squamous cell carcinoma cells in vitro
}

\section{Korvala, Johanna}

2017-01-01

Korvala , J , Jee , K, Porkola , E , Almangush , A, Mosakhani , N, Bitu , C , Cervigne , N K, Zandonadi , F S, Meirelles , G V , Paes Leme , A F , Coletta , R D , Leivo , I \& Salo , T 2017

, ' MicroRNA and protein profiles in invasive versus non-invasive oral tongue squamous cell

carcinoma cells in vitro ' , Experimental Cell Research, vol. 350 , no. 1 , pp. 9-18 . https://doi.org/10.1016/j.yexcr.20

http://hdl.handle.net/10138/233264

https://doi.org/10.1016/j.yexcr.2016.10.015

publishedVersion

Downloaded from Helda, University of Helsinki institutional repository.

This is an electronic reprint of the original article.

This reprint may differ from the original in pagination and typographic detail.

Please cite the original version. 
Research article

\title{
MicroRNA and protein profiles in invasive versus non-invasive oral tongue squamous cell carcinoma cells in vitro
}

\author{
Johanna Korvala $^{\mathrm{a}, *}$, Kowan Jee ${ }^{\mathrm{b}, \mathrm{c}}$, Emmi Porkola ${ }^{\mathrm{a}}$, Alhadi Almangush ${ }^{\mathrm{c}}$, Neda Mosakhani ${ }^{\mathrm{d}}$, \\ Carolina Bitu $^{\mathrm{a}}$, Nilva K. Cervigne ${ }^{\mathrm{e}, \mathrm{f}}$, Flávia S. Zandonadi ${ }^{\mathrm{g}}$, Gabriela V. Meirelles ${ }^{\mathrm{g}}$, \\ Adriana Franco Paes Leme ${ }^{\mathrm{g}}$, Ricardo D. Coletta ${ }^{\mathrm{e}}$, Ilmo Leivo ${ }^{\mathrm{b}, \mathrm{c}}$, Tuula Salo ${ }^{\mathrm{a}, \mathrm{h}}$ \\ a Cancer and Translational Medicine Research Unit, University of Oulu, The Medical Research Center Oulu, Oulu University Hospital, Aapistie 5A, 90014 \\ Oulu, Finland \\ b Department of Pathology, University of Turku, Turku University Hospital, Turku, Finland \\ ${ }^{\mathrm{c}}$ Department of Pathology, Haartman Institute, University of Helsinki, Helsinki, Finland \\ a Department of Pathology, HUSLAB, Helsinki, Finland \\ e Department of Oral Diagnosis, School of Dentistry, University of Campinas (UNICAMP), Av. Limeira, 901 - Bairro Areião, CEP: 13414-903 Piracicaba, São \\ Paulo, Brazil \\ ${ }^{\mathrm{f}}$ Department of Clinical and Pathology, Faculty of Medicine of Jundiai - FMJ, Jundiai, SP, Brazil \\ ' Laboratório Nacional de Biociências, LNBio, CNPEM, Rua Giuseppe Máximo Scolfaro, 10.000, Polo II de Alta Tecnologia de Campinas, Campinas/SP, P.O. \\ Box 6192, CEP 13083-970 Campinas, São Paulo, Brazil \\ h Oral and Maxillofacial Diseases, University of Helsinki and Helsinki University Hospital, Helsinki, Finland
}

\section{A R T I C L E I N F O}

\section{Keywords:}

MicroRNA

Proteomics

Oral tongue squamous cell carcinoma

Bioinformatics

\begin{abstract}
A B S T R A C T
Complex molecular pathways regulate cancer invasion. This study overviewed proteins and microRNAs (miRNAs) involved in oral tongue squamous cell carcinoma (OTSCC) invasion. The human highly aggressive OTSCC cell line HSC-3 was examined in a 3D organotypic human leiomyoma model. Non-invasive and invasive cells were laser-captured and protein expression was analyzed using mass spectrometry-based proteomics and miRNA expression by microarray. In functional studies the 3D invasion assay was replicated after silencing candidate miRNAs, miR-498 and miR-940, in invasive OTSCC cell lines (HSC-3 and SCC-15). Cell migration, proliferation and viability were also studied in the silenced cells. In HSC-3 cells, 67 proteins and 53 miRNAs showed significant fold-changes between non-invasive $v$ s. invasive cells. Pathway enrichment analyses allocated "Focal adhesion" and "ECM-receptor interaction" as most important for invasion. Significantly, in HSC-3 cells, miR-498 silencing decreased the invasion area and miR-940 silencing reduced invasion area and depth. Viability, proliferation and migration weren't significantly affected. In SCC-15 cells, down-regulation of miR498 significantly reduced invasion and migration. This study shows HSC-3 specific miRNA and protein expression in invasion, and suggests that miR-498 and miR-940 affect invasion in vitro, the process being more influenced by mir-940 silencing in aggressive HSC-3 cells than in the less invasive SCC-15.
\end{abstract}

\section{Introduction}

Oral cancer is the most common subgroup of head and neck cancers and the rates of treatment failure and therapy-related morbidity in patients are high because of its regional or distant metastases [15]. Migration and invasion of neoplastic cells are prerequisites for metastasis, which is among the main causes of cancer deaths [53]. Varying histological tumor patterns suggest that cancer cells employ different cellular and molecular invasion modes, which complicates the recognition and understanding of the crucial molecules and pathways involved [10]. Invasion requires molecular modulation of the cancer cells' adhesive, migratory and cytoskeletal properties [10,17].

Proteins regulate cancer cell behavior, and their related biological pathways have been studied previously $[42,63]$. MicroRNAs (miRNAs) can also affect tumor invasion and metastasis, e.g. in breast, liver, prostate and colorectal cancers $[6,51,56]$. At present, over 2500 mature miRNAs are reported for Homo sapiens (miRBase V21, 2014; Welcome Sanger Trust Institutes, Cambridge, UK), yet miRNAs and related

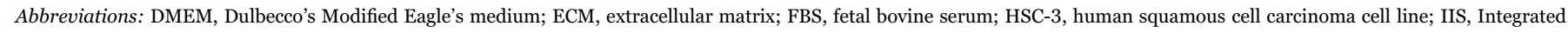
interactome system; miRNA, microRNA; SCC-15, human squamous cell carcinoma cell line; qRT-PCR, quantitative reverse transcription-PCR

* Corresponding author.

E-mail address: johanna.korvala@oulu.fi (J. Korvala). 
pathways in oral cancer invasion have not been fully addressed.

We aimed to compile an overview on proteins and miRNAs involved in oral tongue squamous cell carcinoma (OTSCC) invasion. The highly invasive human tongue squamous cell carcinoma HSC-3 cell line was studied in an in vitro 3D human organotypic invasion assay [39]. Expression profiles of laser-captured non-invasive and invasive cells of the HSC-3 cell line were compared using mass spectrometry and miRNA microarray, respectively. Protein and miRNA results were combined to build a network including pathway enrichment analysis for the Kyoto Encyclopedia of Genes and Genomes (KEGG) pathways involved in invasion. Finally, candidate miRNAs, hsa-miR-498 and -940 , were silenced for functional in vitro studies using more and less invasive OTSCC cell lines.

\section{Material and methods}

\subsection{Cell culture}

Two oral tongue carcinoma (OTSCC) cell lines were used: the aggressive, highly invasive human tongue squamous cell carcinoma HSC-3 (JCRB 0623; Osaka National Institute of Health Sciences, Osaka, Japan) and the less invasive SCC-15 (ATCC; [45]). The cells were cultured in Dulbecco's Modified Eagle's medium (DMEM; Gibco, BRL, Life Technologies, Carlsbad, CA, USA) plus $10 \%$ fetal bovine serum (FBS), $100 \mathrm{U} / \mathrm{ml}$ penicillin-streptomycin, 1\% amphotericin-B and $0.1 \%$ hydrocortisone (all from Sigma-Aldrich, Ayrshire, UK). Cells were grown at $37^{\circ} \mathrm{C}$ and $5 \% \mathrm{CO}_{2}$. See Supplementary Table 1 for detailed description of the cell lines.

\subsection{Myoma organotypic model, immunohistochemistry \& laser microdissection}

The 3D myoma organotypic model was used to study cancer cell invasion [39]. Briefly, myoma discs were preincubated for $48 \mathrm{~h}$ in $10 \%$ FBS-DMEM at $4{ }^{\circ} \mathrm{C}$, after which they were placed in transwells. HSC-3 cells $\left(7 \times 10^{5}\right.$ cells/well) were seeded on the discs and allowed to invade into the myomas for 10 days. The media was changed every 3-4 days.

For isolating non-invasive and invasive cells, the myoma discs were embedded in Sakura Tissue-Tek O.C.T. compound (VWR, Radnor, PA, USA), snap frozen in liquid nitrogen, cut into $10 \mu \mathrm{m}$ sections and stained using cytokeratin AE1/AE3 (M3515, Dako, Glostrup, Denmark). Non-invasive and invasive cells were isolated using a laser microdissection system from PALM Technologies (Carl Zeiss MicroImaging GmbH, Munich, Germany) or LMD7000 (Leica Microsystems, Wetzlar, Germany). The two cell populations were distinguished (Supplementary Fig. 1) and collected separately into tubes under a 10x ocular lens and stored at $-70^{\circ} \mathrm{C}$.

For detecting invasion in the silenced cell lines, myoma discs were fixed overnight in $\mathrm{Zn}$ fixative followed by rehydration and embedding in paraffin [16].

The discs were cut into $6 \mu \mathrm{m}$ sections that were stained using cytokeratin AE1/AE3 (M3515, Dako) and visualized (x5) using a Leica DMRB microscope DFC 480 camera with the Leica application suite v3.8 (Leica Microsystems). Invasion areas and depths were assessed using Image $\mathrm{J}$ v1.46o (National Institute of Health, Bethesda, MD, USA).

\subsection{MicroRNA extraction from non-invasive and invasive $\mathrm{HSC}-3$ cells}

Total RNA including miRNA was extracted using the miRNeasy Mini Kit (Qiagen, Valencia, CA) according to the manufacturer's protocol. RNA qualities and quantities were checked using a NanoDrop ND-1000 Spectrophotometer (NanoDrop Technologies, Wilmington, Delaware, USA) and verified with an Agilent 2100 Bioanalyzer using RNA Nano 6000 and Small RNA Chips according to the manufacturer's protocol (Agilent Technologies Inc., Palo Alto, $\mathrm{CA})$.

\subsection{MiRNA microarray hybridizations, image scanning and feature extraction}

Agilent's SuperPrint G3 Human miRNA microarray System (V16, Agilent Technologies, Santa Clara, CA, USA) was used following the manufacturer's protocol. The slides were washed and scanned in a high-resolution Microarray Scanner (G2565CA, Agilent Technologies Inc.). Scanned images were digitized with Agilent Feature Extraction Software v.9.5.

\subsection{Identification of differentially expressed miRNAs in HSC-3 cells}

Statistical analyses to identify differentially expressed miRNAs between non-invasive and invasive cells were done with GeneSpring GX (v12.0). Text files gained from the Feature Extraction software were up-loaded into GeneSpring GX, assigning the interpretation parameters ("non-invasive" and "invasive"). Experimental qualities of the arrays were verified, expression signals were normalized at the 75th percentile of raw signal values and baseline transformation was set at the median of each array. MiRNAs not detected in any samples were excluded. To identify significantly altered miRNA expression levels between non-invasive and invasive cells, the unpaired $t$-test was used with an adjusted $\mathrm{p}$ value at $<0.05$ and fold-change with adjustables. Quantitative RT-PCR (qRT-PCR) was used to validate some of the differentially expressed miRNAs.

\subsection{Validation of miRNA microarray and differentially expressed miRNAs by $q R T-P C R$}

For validating the microarray expression results, four over-expressed (miR-498, miR-940, miR-1207-5p and miR-1238) and two evenly expressed microRNAs (miR-106b and miR-125b) and the housekeeping gene U6 (SnRNA U6; Qiagen) were assayed using Light-Cycler (Roche Applied Science, Mannheim, Germany) and primers from Qiagen (Valencia, CA) or GeneCopoeia (Rockville, MD, USA). MiRNAs were selected from the two main KEGG pathways in our networks, namely "Focal adhesion" (miR-1207-5p and miR-1238) and "Extracellular matrix (ECM) receptor interaction" (miR-498 and miR940). The latter ones were also chosen as candidates to be silenced for functional assays as they were among the most up-regulated miRNAs in invasive $v s$. non-invasive cells (Supplementary table 2), and also based on previous literature. The remaining RNA samples were pooled for HSC-3 to perform quantitative reverse transcription-PCR (qRTPCR). RNA (300 ng) was converted into cDNA using the miScript Reverse Transcription Kit (Qiagen) and qRT-PCR was done using a SYBR Green miScript PCR System (Qiagen) according to the manufacturer's instructions. Samples were treated as duplicates. The relative amounts of miRNA expressions were calculated using the $2_{\mathrm{T}}^{-\Delta \Delta \mathrm{C}}$ method [35].

\subsection{Analysis of miR-498 and miR-940 expressions in oral squamous cell carcinoma (OSCC) samples}

The expression of miR-498 and miR-940 was assessed in fresh tumor specimens $(\mathrm{n}=12)$ and a pool of normal oral mucosa samples $(n=12)$. The tumors located in tongue (7), floor of mouth (2), retromolar area (2), and one containing sample from both tongue and floor of mouth. Tumor grades varied between well differentiated (5), moderately differentiated (5) and poorly differentiated (2). Briefly, $1 \mu \mathrm{g}$ of total RNA was converted into specific cDNA derived from mature microRNAs using TaqMan microRNA Reverse Transcription Kit (Applied Biosystems, USA) and quantified in triplicates using the TaqMan microRNA assay. The small nucleolar RNA (snoRNA) RNU6 
was used as endogenous control. All assays were obtained from Applied Biosystems through their Assay-on-Demand service. Data were quantified and analyzed using sequence detection system (version 2.3) (Applied Biosystems, USA). MicroRNA relative expression in fresh tumor specimens was normalized against endogenous control and pooled normal oral mucosa samples $(n=12)$.

\subsection{Sample preparation for mass spectrometry}

Microdissected sections were treated with $1.6 \mathrm{M}$ urea, followed by reduction ( $5 \mathrm{mM}$ dithiothreitol, $25 \mathrm{~min}$ at $56{ }^{\circ} \mathrm{C}$ ), alkylation $(14 \mathrm{mM}$ iodoacetamide, $30 \mathrm{~min}$ at room temperature in the dark) and digestion with trypsin $(1: 50, \mathrm{w} / \mathrm{w})$. The reaction was stopped with $0.4 \%$ formic acid and desalted using Stage Tips [2,44]. Samples were dried in a vacuum concentrator and reconstituted in $0.1 \%$ formic acid. LC-MS/ MS analysis, protein identification and quantitative analysis are described in the Supplementary material. Mass spectrometric raw and msf files are available for download via FTP from the PeptideAtlas data repository (http://www.peptideatlas.org/ PASS00751/).

\section{9. $L C-M S / M S$ analysis}

Nanoflow nLC-MS/MS: The mixture of peptides was analyzed on an ETD-enabled LTQ Orbitrap Velos mass spectrometer (Thermo Fisher Scientific) connected to a nanoflow liquid chromatography (LC-MS/ MS) instrument by an EASY-nLC system (Proxeon Biosystem) with a Proxeon nanoelectrospray ion source. Peptides were separated with a $2-90 \%$ acetonitrile gradient in $0.1 \%$ formic acid using an analytical PicoFrit Column ( $20 \mathrm{cmxID} 75 \mu \mathrm{m}, 5 \mu \mathrm{m}$ particle size, New Objective) at a flow rate of $300 \mathrm{~nL} / \mathrm{min}$ over $80 \mathrm{~min}$. The nanoelectrospray voltage was set to $2.2 \mathrm{kV}$ and the source temperature was $275^{\circ} \mathrm{C}$. All of the instrument methods were set up in the data-dependent acquisition mode. The full scan MS spectra $(\mathrm{m} / \mathrm{z} 300-1600)$ were acquired in the Orbitrap analyzer after accumulation to a target value of $1 \times 10^{6}$. The resolution in the Orbitrap was set to $r=60,000$ and the 20 most intense peptide ions with charge states $\geq 2$ were sequentially isolated to a target value of 5,000 and fragmented in the linear ion trap using low-energy CID (normalized collision energy of 35\%). The signal threshold for triggering an MS/MS event was set to 1,000 counts. Dynamic exclusion was enabled with an exclusion size list of 500, exclusion duration of $60 \mathrm{~s}$, and a repeat count of 1 . An activation $\mathrm{q}=0.25$ and activation time of $10 \mathrm{~ms}$ were used [2].

\subsection{Protein identification and quantitative analysis}

Protein identification and quantitative analysis were performed as described in [26]. The raw files were processed using the MaxQuant version 1.2.7.429 and the MS/MS spectra were searched using the Andromeda search engine [8] against the Uniprot Human Protein Database (release Jun, 2013; 88,771). The initial maximal allowed mass tolerance was set to $20 \mathrm{ppm}$ for precursor and then set to $6 \mathrm{ppm}$ in the main search and to 0.5 Da for fragment ions. Enzyme specificity was set to trypsin with a maximum of two missed cleavages. Carbamidomethylation of cysteine (57.021464 Da) was set as a fixed modification, and oxidation of methionine (15.994915 Da) and protein $\mathrm{N}$-terminal acetylation (42.010565 Da) were selected as variable modifications. The maximum PEP was set to 1 , and the minimum peptide length was set to 7 amino acids. Only proteins with at least two peptides (thereof one uniquely assignable to the respective protein group) were considered as reliably identified.

Based on Hubner [20], label-free protein quantification was switched on, and unique and razor peptides were considered for quantification with a minimum ratio count of 1 . For protein quantification, LFQ was set and the 'requantify' and 'match between runs' with 2 min of time window functions were enabled. At least two quantitation events were required for a quantifiable protein.

The false discovery rates (FDRs) of peptide and protein were both set to 0.01 . Only proteins with at least two peptides (thereof one uniquely assignable to the respective protein group) were considered as reliably identified.

Bioinformatic analyses were performed using Perseus v.1.2.7.429, which is available in the MaxQuant environment. First, reverse and only identified by site entries were excluded from further analysis. Label-free quantification was performed using the normalized spectral protein intensity (LFQ intensity). Data obtained from one experiment from each cell line and condition (non-invading and invading) were described as HSC_A or C groups and the data were converted into log2. The protein ratios were calculated from the median of all normalized protein intensity.

\subsection{Pathway enrichment analyses \& combining proteomic and miRNA data}

The differences of expression between non-invasive and invasive cells were the focus of this study. The proteomics enrichment for KEGG pathways and network files for proteins with statistically significant fold-changes were created using the Integrated interactome system (IIS; [5]. The proteomic networks were built by setting a $\log \mathrm{FC}$ cut off to $\leq-0.6$ for the down-regulated proteins and to $\geq 0.6$ for the upregulated ones [5]. For miRNA pathway enrichment analyses, miRNAs with statistically significant fold-changes between non-invasive and invasive cells were inserted into mirPath 2.0 [58] and filtered by a list of target proteins expressed in the equivalent myoma invasion assay with statistically significant fold-changes.

Finally, miRNA and proteomic data were combined and the network visualized in Cytoscape v2.8.3 [50,52]. MiRNAs were assigned only to one pathway and target gene based on their highest p-values. Interesting Top KEGG pathways were selected based on the following criteria: 1) $\mathrm{P}$ value $<0.05,2)$ more than three miRNAs or proteins assigned in a cluster, 3) pathways associated with specific non-cancer related diseases or viral conditions were excluded.

\subsection{Silencing candidate miRNAs in OTSCC cells}

Lentiviral miRNA inhibitors for hsa-miR-498 and -940 and the control (HmiR-AN0541-AM03, HmiR-AN0845-AM03 and HmiRAN0001-AM03; GeneCopoeia Inc., Rockville, MD, USA) were produced in 293Ta packaging cells using the Lenti-Pac HIV expression packaging kit (GeneCopoeia Inc., Rockville, MD, USA) according to the manufacturer's instructions. Two days before transfection $1.4 \times 10^{6}$ 293Ta cells were plated on $10 \mathrm{~cm}$ plates. Lentiviral particles were harvested $48 \mathrm{~h}$ later and stored in $-70^{\circ} \mathrm{C}$.

HSC- 3 and SCC-15 cells were plated at $9 \times 10^{4} /$ well on 24 -well plates $24 \mathrm{~h}$ prior to transduction. The cells were transduced by using $370 \mu \mathrm{l}$ of collected lentiviral medium in $10 \%$ FBS-DMEM $(500 \mu \mathrm{l})$ supplemented with $5 \mu \mathrm{g} / \mathrm{ml}$ Polybrene (Sigma) following the manufacturer's protocol (GeneCopoeia Inc., Rockville, MD, USA). Hygromycin $(5 \mu \mathrm{g} / \mathrm{ml})$ selection was carried out over two weeks to establish stably silenced cell lines.

\subsection{Cell viability and proliferation assays}

Cells were plated on 96 -well plates $\left(5 \times 10^{3}\right.$ cells/well). Cell lines were seeded on eight wells and assays performed $48 \mathrm{~h}$ later. An MTT assay was used to compare cell viability and a BrdU assay was used to assess proliferation between silenced HSC-3 and SCC-15 cell lines and the corresponding control cells. MTT (Cell growth determination kit, Sigma-Aldrich, St. Louis, Missouri, USA) and Cell proliferation ELISA, BrdU, assays (Roche, Mannheim, Germany) were performed according to the manufacturer's protocol. Absorbances were read using a Victor ${ }^{3} \mathrm{~V}$ 1420 Multilabel Counter (Perkin Elmer Life \& Life Technologies, 
Waltham, MA, USA)

\subsection{Horizontal cell migration assay}

Horizontal migration assays were performed to assess the effect of miR-498 and miR-940 silencing on HSC-3 and SCC-15 cell migration. HSC- 3 cells were plated at $9 \times 10^{4} /$ well ( $48 \mathrm{~h}$ prior to assay) and SCC- 15 cells at $2.5 \times 10^{5} /$ well ( $24 \mathrm{~h}$ prior to assay) on 24 -well plates. An empty area (a wound) was created amid confluent cells by removing cells using a sterile $1000 \mu \mathrm{l}$ pipette tip (Sartorius, Göttingen, Germany). Cells were washed twice with $1 \times$ PBS, and kept in $1 \%$ FBS-DMEM during migration. Migration was documented every $3 \mathrm{~h}$ until wound closure at $12 \mathrm{~h}$ for HSC-3 and continued at 15, 24, 27, 30 and $48 \mathrm{~h}$ for SCC-15 cells using an EVOS fl microscope (Advanced Microscopy Groups, Mill Creek, WA, USA). Each cell line was treated in triplicate.

Statistical analyses for in vitro assays were calculated using oneway ANOVA followed by Tukey's post hoc test using IBM SPSS Statistics v21.0 (IBM Corp. Armonk, NY, USA).

\subsection{Search for putative target gene for candidate miRNA}

Since miR-940 and Macrophage-capping protein (CAPG) pair seemed the most promising candidate miRNA- target gene pair based on bioinformatics (please see the Results section) and recent literature $[9,11,12,30,60,66]$, our aim was to verify if CAPG expression was affected by miR-940 silencing. As the original expression differences were observed in invading HSC-3 cells, two approaches in which the silenced anti-miR-940 HSC-3 cells were either invading or migrating were used to study the miR-940 - CAPG interaction. Total RNA was isolated for qRT-PCR and protein for Western blot analyses from both study set-ups.

Firstly, invasive anti-miR-940 HSC-3 cells and corresponding controls (anti-miR-ctrl) were captured from cryosections produced in the myoma invasion assay using laser microdissection as described before. Myoma tissue surrounding the invasive cancer cells was captured at the same time and used as control. Total RNA was isolated using RNeasy Mini Kit (Qiagen) and protein with elution buffer (50 mM Tris-Cl pH 7,5; $10 \mathrm{mM} \mathrm{CaCl} 2 \cdot 2 \mathrm{H}_{2} \mathrm{O} ; 150 \mathrm{mM} \mathrm{NaCl} ; 0,05 \%$ Brij 35) with an overnight incubation at $+4^{\circ} \mathrm{C}$, followed by a centrifugation at $14000 \mathrm{rpm}$ for $10 \mathrm{~min}$ at $+4{ }^{\circ} \mathrm{C}$.

Secondly, we performed a migration assay on myogel coated [47] six well plates and compared CAPG expression between migrating and non-migrating anti-miR-940 and anti-miR-ctrl HSC-3 cells. Cells were plated on 6 well plates $\left(7.5 \times 10^{5}\right.$ cells/well) in triplicates and wounds were created as presented above. Migration was followed microscopically in 0.5\%FBS-DMEM and cells were harvested when they were all migrating (at $5 \mathrm{~h}$ ). RNA and protein were isolated using TRIzol $^{\circledR}$ reagent (Thermo Scientific) according to manufacturer's instructions.

From the RNA samples cDNA was synthesized using SuperScript ${ }^{\text {TM }}$ First-strand synthesis system for RT-PCR (Invitrogen). FastStart Universal SYBR Green Master (ROX) -kit (Roche) was used in qRTPCR, reactions run in the CFX96 Real-Time System (BioRad) and results analyzed in CFX Manager v3.0 -software (BioRad). GAPD was used as a reference gene, the PCR primers (available upon request) were ordered from Sigma. The relative amounts of CAPG expressions were calculated using the $2_{\mathrm{T}}^{-\Delta \Delta \mathrm{C}}$ method [35].

For protein analysis a total of $13 \mu \mathrm{g}$ of protein was loaded into each well on $12 \%$ SDS-PAGE (BioRad) under reducing conditions. Proteins were transferred onto Immobilon-P membranes (Immobilon) and unspecific binding was blocked with $5 \%$ non-fat dry milk solution. The primary antibody used was monoclonal CAPG (ab89511; Abcam; 1:500 dilution) and the secondary antibody was biotinylated polyclonal rabbit anti-mouse (1:1000, Dako). Ponceau staining was used to as a loading control (Sigma; data not shown). Pierce ECL Plus Western blotting substrate (Thermo Scientific) and LAS3000 Lite equipment were used for visualization.
A)

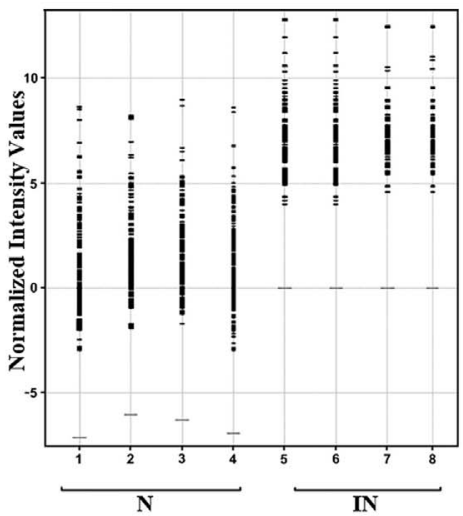

B)
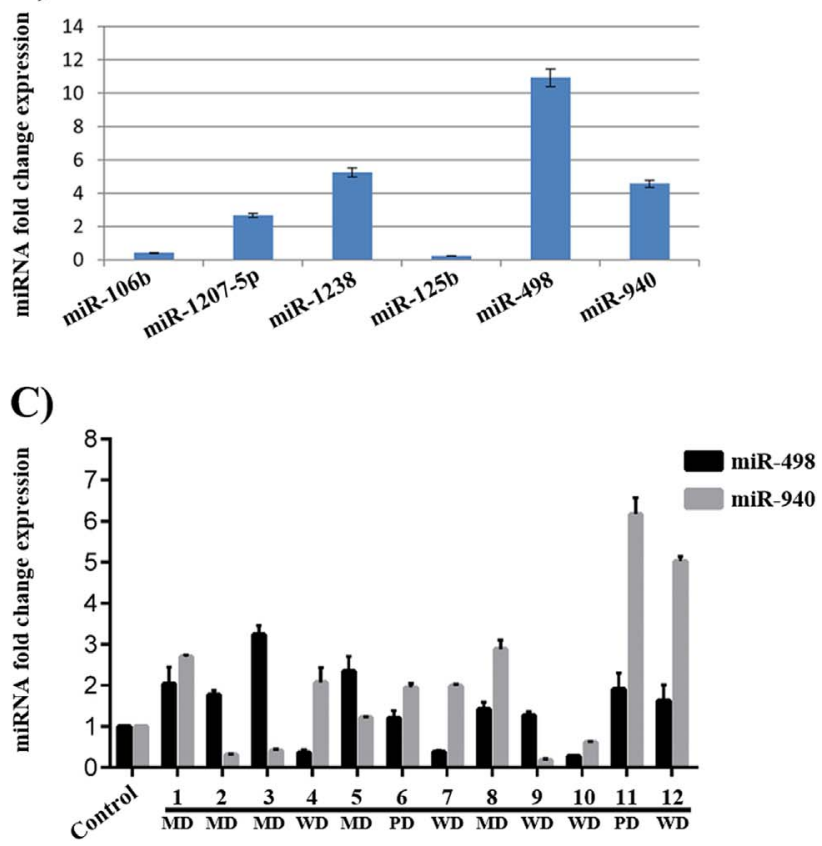

Fig. 1. MicroRNA expression profiles for HSC-3 (A \& B) cells and for fresh oral squamous cell carcinoma specimens (C). Results are shown in BoxWhisker plot. On the $\mathrm{X}$-axis, numbers $1-4$ indicate non-invasive (N) cells (4 samples collected) and their corresponding invasive cells (IN) are indicated as numbers 5-8. Two clusters were formed according to similar miRNA expressions by clustering factors given in the GeneSpring GX. Y-axis indicates logarithmic scales (log2) for the miRNA expression intensities. Expressions of six selected miRNAs (miR-106b, miR-1207-5p, miR-1238, miR-125b, miR-498 and miR-940) were measured by qRT-PCR (B). MiR-498 and miR940 expressions were analyzed from fresh tumor specimens of 12 patients (1-12) and pooled normal oral mucosa samples. Specimens 1 and 9 were collected from floor of mouth, 2, 4-5, 8 and 10-12 from tongue, 3 and 7 from retromolar area and specimen 6 was collected from tongue and floor of mouth. MicroRNA relative expression in fresh tumor specimens was normalized against endogenous control and pooled normal oral mucosa samples $(\mathrm{n}=12)(\mathrm{C})$. Patient numbers and tumor grades are given below the $\mathrm{x}$ axis $(\mathrm{WD}=$ Well differentiated i.e. low grade; $\mathrm{MD}=$ Moderately differentiated i.e. intermediate grade and PD = Poorly differentiated i.e. high grade). Data for each miRNA are shown as the fold expression (calculated as $2_{\mathrm{T}}^{-\Delta \Delta \mathrm{C}}$; [34]) relative to SnRNA U6.

\section{Results}

3.1. MiRNA expression signatures between non-invasive and invasive HSC-3 cells

Significant differences in miRNA expression profiles in non-invasive vs. invasive HSC-3 cells were identified (Fig. 1). Among the 1392 miRNAs present on the array chip, 95 miRNAs differed in HSC-3 (Supplementary Table 2). The majority of miRNAs were up-regulated 
and only let-7e and miR-19a were significantly down-regulated in invasive cells (adjusted $\mathrm{p}$-value $<0.05$ and fold change $\leq 0.5$ ).

\subsection{Validation of miRNA expressions by qRT-PCR in HSC-3 cells and in OSCC samples}

The qRT-PCR results for the 6 miRNAs were compatible with the microarray results after normalization with housekeeping gene SnRNA U6 (Fig. 1B). MiR-498 expression fold changes in HSC-3 were higher in qRT-PCR than in the microarray results.

The miR-498 and miR-940 expressions were surveyed also from OSCC and normal oral mucosa samples. MiRNA expressions were slightly increased in most OSCC samples ( 9 and 8 out of 12 for miR498 and miR-940, respectively), but clear expression profiles could not be distinguished (Fig. 1C).

\subsection{Mass spectrometry of HSC-3 cells}

In HSC-3 cells a total of 354 proteins were identified and quantitated. Exogenous contaminants, protein duplicates and proteins that could not be quantified or were not exclusively expressed in either cell population were excluded from further analyses. After filtering, 321 proteins were present in HSC-3 cells and of these 31 were exclusive for non-invasive and 190 for invasive cells (Supplementary Table 3).

\subsection{Protein and miRNA networks of HSC-3 cells}

Proteins and miRNAs associated with invasion were annotated in specific KEGG pathways. The most striking observation was the expression profiles as the majority of proteins, miRNAs and their interactions were up-regulated (Fig. 2). Of the 67 proteins in the HSC-3 network, $66.7 \%$ were up-regulated, $15.0 \%$ were down-regulated and $18.3 \%$ were non-regulated. Pathway analyses annotated the majority of these proteins to "Focal adhesion" (Supplementary Table 4). The HSC3 network contained 53 miRNAs, which were all up-regulated. Of these miRNAs $77.8 \%$ were annotated to "ECM-receptor interaction" (Supplementary Table 5).

At last the expressions of candidate miRNAs, miR-498 and miR940, and their target proteins in invasive HSC-3 cells were compared. Altogether thirteen target proteins were paired with miR-498 and twelve with miR-940 in invasive HSC-3 s cells in the miRNA - protein network compiled in Interactive interactome system (IIS; [5] (Supplementary Table 6). Of these only one miRNA - target protein pair, namely miR-940 - Macrophage-capping protein (CAPG), had inverted expression pattern (Supplementary Table 6). Overall, CAPG was one of the few proteins that was down-regulated in invasive HSC-3 cells.

\subsection{Cell viability, proliferation and horizontal migration assays using silenced OTSCC cell lines}

MiR-498 and mir-940 were selected for functional assays because they were among the most up-regulated miRNAs in invasive cells and have also been implicated in other cancers [14,43,59], but they have not been studied in tongue cancer. Moreover, they were involved in the enriched "ECM-receptor interaction" pathway, which consists of a complex mixture of macromolecules controlling cellular activities such as adhesion, migration and apoptosis. Therefore, to understand the role of the selected miRNAs, two OTSCC cell lines were used: HSC-3 (highly invasive) and SCC-15 (less invasive).

First, cell viability and proliferation were studied in miRNAsilenced cells. Anti-miR-498 and -940 silencing did not affect HSC-3 proliferation or viability (Fig. 3A-B). However viability was increased in the less invasive SCC-15 cells treated with anti-miR-498 compared to anti-control (Fig. 3C). Both viability and proliferation were even more increased in SCC-15 treated with anti-miR-940 compared to anti-miR-
498 and anti-control (Fig. 3C-D).

For HSC-3 migration, a decreased trend was observed in anti-miR498 and anti-miR-940 compared to anti-control (Fig. 3E-F). Wound closure was slower in SCC-15 than in HSC-3 cells. Migration was reduced significantly in SCC-15 anti-miR-498 compared to anti-miR940 and anti-control, and migration was fastest in anti-miR-940 (Fig. 3G-H).

\subsection{Myoma invasion using silenced OTSCC cell lines}

Next the 3D invasion of silenced cells was analyzed. Invasion depth was decreased in HSC-3 anti-miR-940 compared to anti-miR-498 and anti-control ( $\mathrm{p}<0.001$ for both), and invasion area was reduced in anti-miR-498 and anti-miR-940 compared to anti-control ( $\mathrm{p}<0.001$ for both) (Fig. 4A-C). In SCC-15 anti-miR-498 invasion depth was decreased compared to anti-miR-940 and anti-control ( $\mathrm{p}<0.05$ and $\mathrm{p}$ $<0.001$, respectively), and invasion area was reduced compared to anti-miR-940 (p<0.05) (Fig. 4D-F).

\subsection{Search for target genes for candidate miR-940}

As assessed using qRT-PCR no difference was observed in the expression of CAPG between the invasive anti-miR-940 HSC-3 cells and control samples captured from the myoma invasion assay. The average relative fold changes were 0,947 and 0,935 for anti-miR-940 and control, respectively. No difference was observed in CAPG expression of migrating cells either, the fold changes relative to non-migrating cells being 1,760 for miR-940 and 1,860 for miR-control. (Supplementary Fig. 2A).

Unfortunately the protein yield from the laser microdissected samples was too low for successful Western blot analysis on CAPG expression. However, the results from Western blot of migrating cells were consistent with the qPCR finding with no difference in CAPG protein levels between anti-miR-940 and anti-miR-control HSC-3 cells (Supplementary Fig. 2B).

\section{Discussion}

In this study, miRNAs, proteins and related pathways associated with invasion of the highly invasive OTSCC cell line HSC-3 were overviewed. Marked differences in expression patterns, fold-changes and interactions were observed between invasive and non-invasive cells. Interestingly, expression was mostly up-regulated in HSC-3 invasive cells. Though miRNAs are often down-regulated in cancer, up-regulated or increased expressions have been observed related to cancer metastases [1]. Indeed, two recent review articles outlined several miRNAs to be up-regulated in neck squamous cell carcinomas (HNSCC) [38] and/or HNSCC metastases [23], coinciding with our results. Surprisingly, comparison of candidate miRNAs, miR-498 and miR-940, and their target protein expressions revealed only one pair (miR940 - CAPG) with inversed regulation, while the other miRNA target protein pairs were up-regulated in parallel manner. Although miRNAs mostly down-regulate target protein expression, there is some evidence of miRNAs also increasing the expression of their target genes $[61,57])$. Future research will reveal, if this applies in HSC-3 invasion.

Eight KEGG pathways were annotated to networks in invasive HSC3 cells and hence considered central in invasion. The majority of proteins and miRNAs (highest statistical significances) were annotated to processes of "Focal adhesion", "ECM-receptor interaction" and "Regulation of actin cytoskeleton." These functions of cell attachment and movement have also been previously annotated in invasion and metastasis processes in lung adenocarcinoma [19] and in muscle invasive bladder cancer [4]. Interestingly, up-regulated proteins in buccal carcinoma were also annotated into "Focal adhesion", "Regulation of actin cytoskeleton" and "Cell cycle" [46].

Recently Xiao et al. [63] performed a comparative proteomic study 


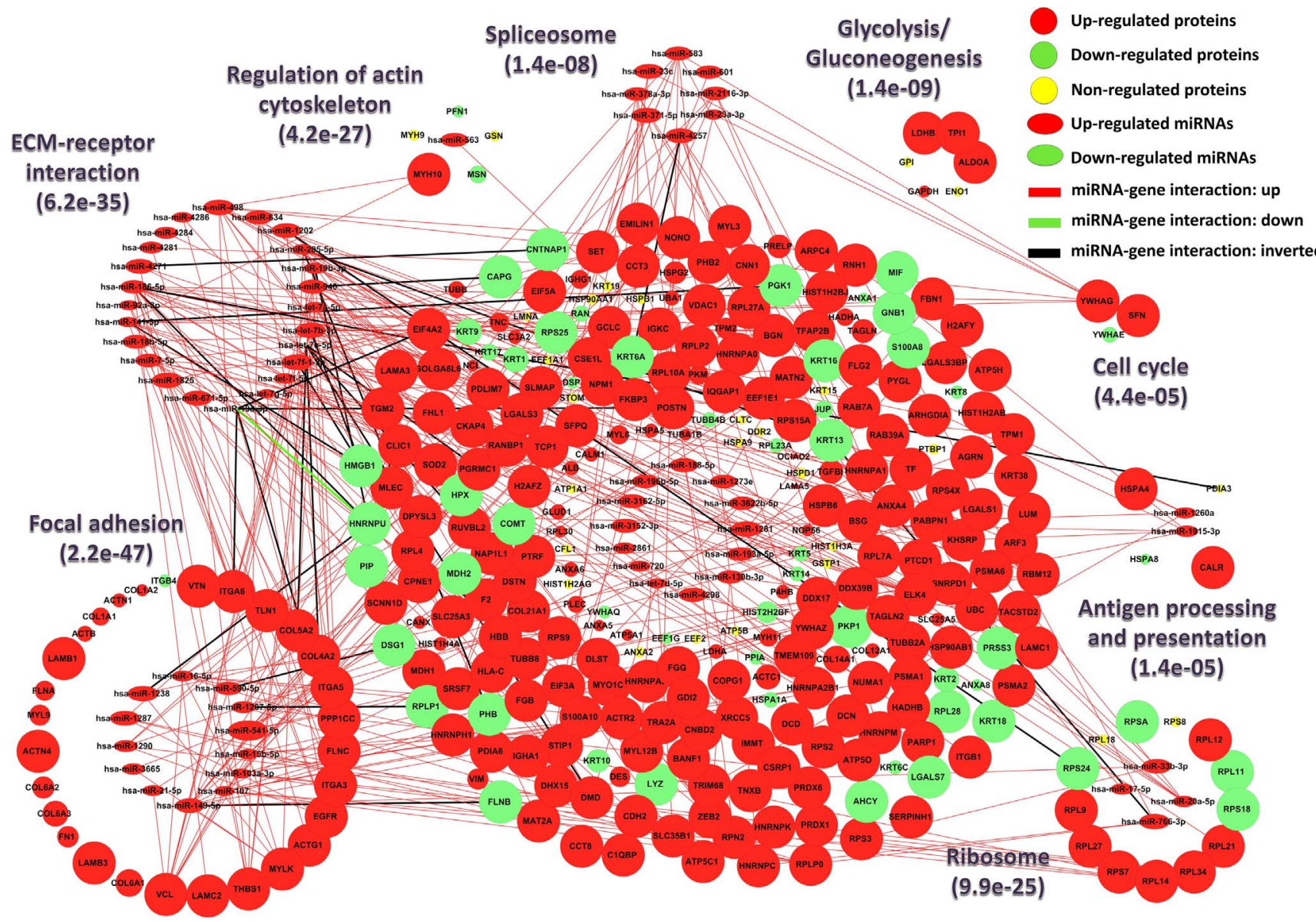

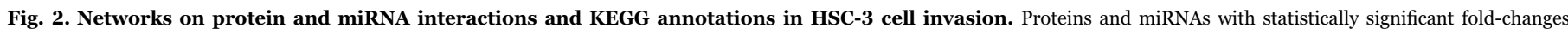

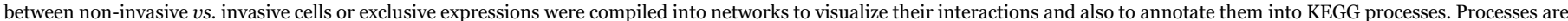

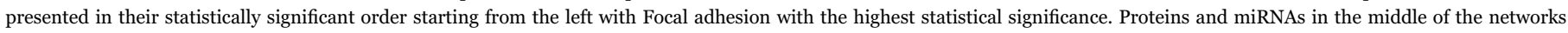

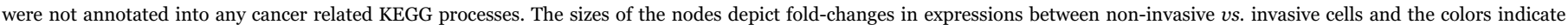
expression patterns.

to discover expression differences between epithelial dysplasia and normal epithelia from 19 patients. Ten of the 32 differentially expressed proteins (Annexin A1, Keratin 1 and S100 calcium-binding protein A8, Myosin light chain $1 / 3$, Cardiac muscle alpha actin 1 proprotein, Putative uncharacterized protein, Tenascin, Manganesecontaining superoxide dismutase, Gelsolin isoform b and Myosin-10) were also detected and similarly expressed in the invasive $v$ s. noninvasive HSC-3 cells in our 3D myoma invasion assay. Our results not only support the previous research, but also define and implicate a possible role for these proteins specifically in HSC-3 invasion.

Two miRNAs that were up-regulated in invasive $v s$. non-invasive HSC-3 cells were chosen for functional assays of two OTSCC cell lines. Silencing of miR-498 and miR-940 had effects on both of these cell lines, but there were differences between the less and more aggressive cells in the 2D and 3D assays. Importantly, invasion depth and/or area were significantly reduced in both silenced OTSCC cell lines, showing the relevance of these miRNAs particularly in invasion in the 3D model. However, miRNA and cell line specific differences were observed as anti-miR-940 decreased depth of invasion in HSC-3 but not in SCC-15 cells, and anti-miR-498 reduced invasion depth in SCC-15 while showing no effect on HSC-3. Invasion area was decreased with both miRNA silencing in HSC-3, while in SCC-15 only anti-miR-498 had a lower invasion area compared to anti-miR-940. In general, miRNA silencing had a greater effect on the less invasive SCC-15 cells than on the more invasive HSC-3 cells. Silencing had no significant effect on migration, cell viability or proliferation of HSC-3 cells. In contrast, in SCC-15 anti-miR-498 and anti-miR-940 increased the viability, and
anti-miR-940 pormoted the proliferation of the cells. This difference between these cell lines might be explained by the fact that HSC-3, as a highly aggressive cell line, may not be that susceptible to such miRNA induced changes.

To validate the significance of miR-498 and miR-940 in OSCC, additional in vivo research is necessary. Here we analyzed the two miRNAs' expressions from a group of OSCC and normal mucosa samples, but evident expression profiles for miRNAs were not observed. To have a better understanding on these miRNAs in OSCC in vivo, further research needs to be performed on bigger sample sizes and more detailed descriptions on the patients. For instance it would be of interest to see, if higher miRNA expressions correlate with increased invasion or cancer aggressiveness. In addition, as part of the future in vivo studies it would be prominent to analyze and compare the miRNA expressions not only from solid tumors, but also from related metastases, since miRNAs were up-regulated in invasive $v s$. non-invasive cells in the principal in vitro assay.

Both miR-498 and miR-940 have been implicated in the tumorigenesis of several cancers. MiR-498 is among the miRNAs upregulated by hypoxia in oral SCC [18]. Furthermore miR-498 is down-regulated in stage II colon cancer $[14,49]$ and its high expression correlates with longer survival in stage II colon cancer [49]. On the contrary, decreased miR-498 expression was detected in two studies on ovarian cancer [7,32], where it associates with poor overall survival and prognosis of patients [7] or controls cell proliferation by targeting FOXO3 [32]. Decreased miR-498 expression is observed also in nonsmall lung cancer correlating with tumor progression [59]. In vitro up- 

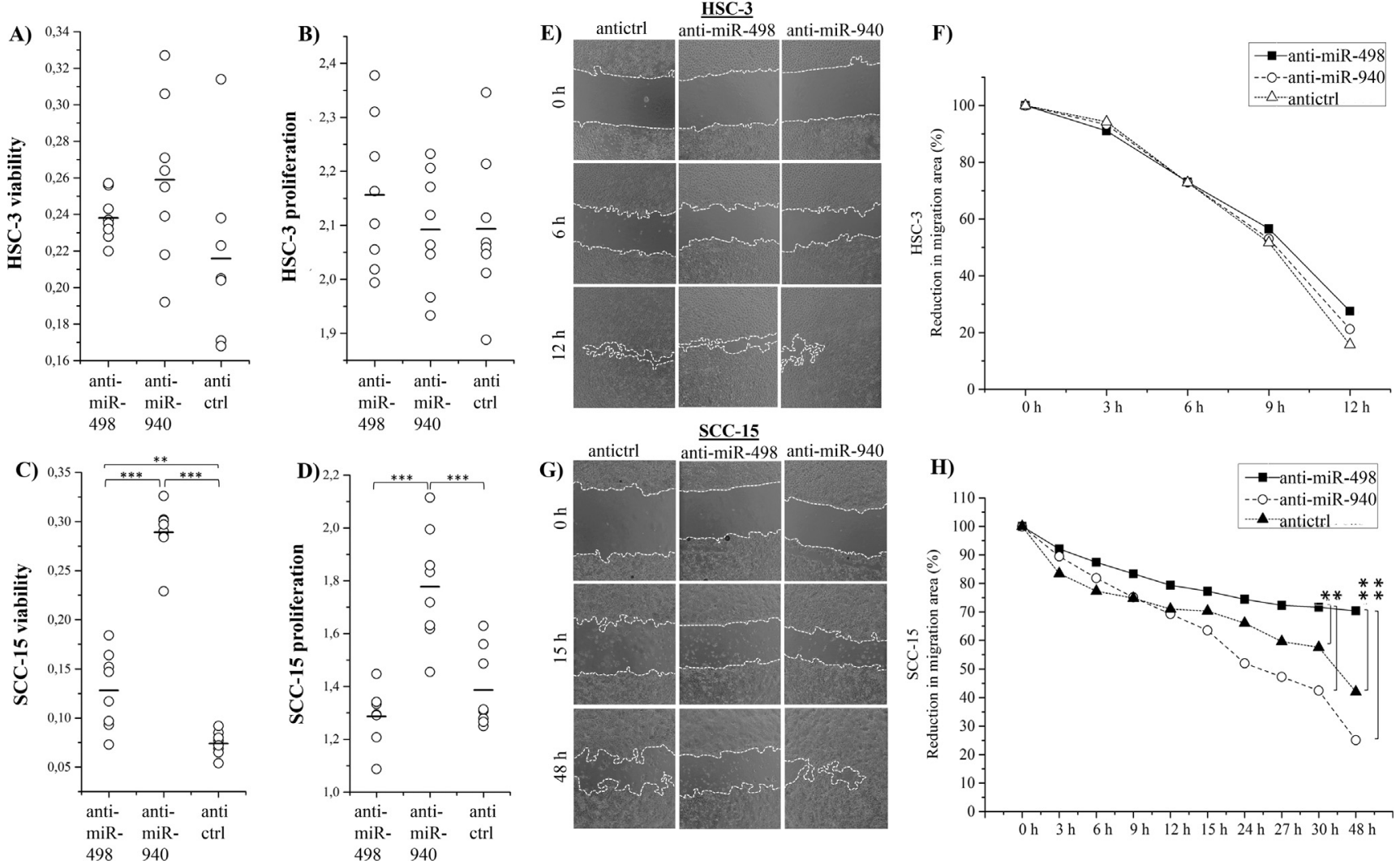

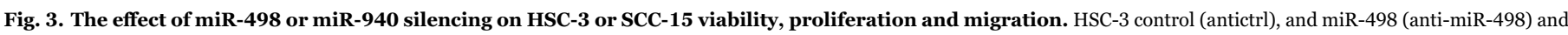

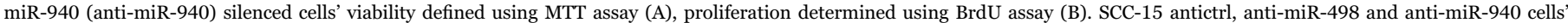

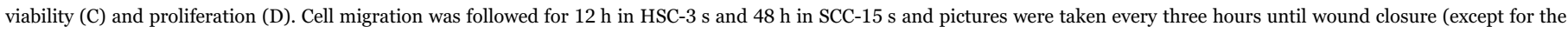

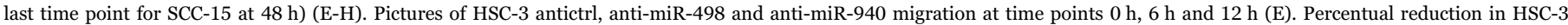

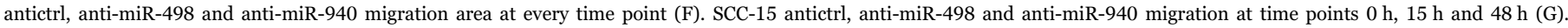

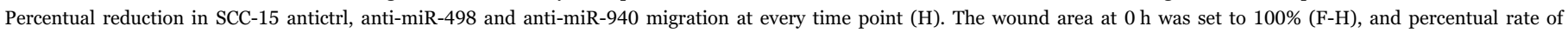
migration was calculated and compared between cell lines. Assays were performed in sextuples for each cell line. ${ }^{*} \mathrm{P}<0.05$; ${ }^{* *} \mathrm{P}<0.01 ;{ }^{* * *} \mathrm{P}<0.001$.

regulation of miR-498 in SW480 colon cancer reduces cell proliferation and increases the number of cells in G2-M phase [14]. The above results are in line with our invasion assays. Nonetheless, miR-498 is highly expressed in retinoblastoma [67] and up-regulated in medullary thyroid carcinoma metastatic tumors [48] and in triple negative breast cancer, where it promotes cancer cell proliferation via down-regulation of BRCA1 [37]. These data underline the multifaceted role of miR-498 in cancer. Regarding the functional side, miR-498 has been shown to down-regulate the human epidermal growth factor receptor 2 (HER2)pathway in breast cancer [28], and in ovarian cancer it mediates the $1,25(\mathrm{OH})_{2} \mathrm{D}_{3}$ 's (calcitriol) effect on tumor suppression and apoptosis [24,25].

MiR-940 has not been reported in tongue cancer before, and information in other cancers is still sparse and contradictory. Prostate cancer cells treated with miR-940 in vitro migrated and invaded more slowly than control cells and conversely, inhibition of miR-940 increased invasion [43]. In pancreatic carcinoma miR-940 overexpression increases cell proliferation and invasion via GSK3 $\beta$ and sFRP1 [64], while in gastric cancer miR-940 induces cancer invasion through ZNF24 down-regulation [33]. In another study on gastric cancer miR-940 levels were down-regulated in patient plasma, cancer tissue samples and cancer cell lines and biomarker role was suggested for miR-940 [34]. At the same time down-regulation of miR-940 was detected in hepatocellular carcinoma, where it induced cell proliferation by targeting estrogen-related receptor gamma [65], and in pancreatic ductal adenocarcinoma, where it correlated with poor patient survival and promoted cell proliferation via targeting Myeloid differentiation primary response gene (88) [54]. Another study showed miR-940 decreased human telomerase-immortalized retinal pigmented epithelial (RPE1) cell migration [3]. Additionally, miR-940 in nasopharyngeal carcinoma inhibits cancer cell proliferation, arrests the cell cycle, promotes apoptosis and inhibits xenograft tumor formation [36]. Our results indicated that SCC-15 anti-miR-940 cells were the fastest to migrate. However, silencing miR-940 in HSC-3 cells reduced invasion depth and area, but in SCC-15 cells anti-miR-940 did not have similar effect. Differences in results of miRNA silencing are likely due to cancer and cell line specific characteristics.

The differences between the migration and invasion assay results may be explained by the experimental matrixes as invasion was studied on a 3D myoma organotypic model, which closely mimics the tumor microenvironment, and the migration assay was performed on plain plastic well plates. It is noted that cell migration on plastic surfaces does not thoroughly replicate cell behavior in vivo. However to date there are no solid options for examining migration in in vitro conditions that would ideally represent those of in vivo situation [27]. Horizontal cell migration assay was chosen for this study, as it is a generally used and accepted method to examine collective cell migration in cellular monolayer [41]. It is commonly used also in studying head and neck squamous cell carcinoma migration and adaptations of this method are also applied to study cell invasion [21]. The method is easy to perform, it doesn't require any special equipment, and it provides high throughput data and enables live imaging [31,41].

Meanwhile it is also recognized that at the present the actual function of these two miRNAs is yet to be determined in OTSCC invasion, and thus the current results should be considered with moderation. Indeed besides computationally predicted pathways in the current work, it is essential to find and establish specific target 
A)

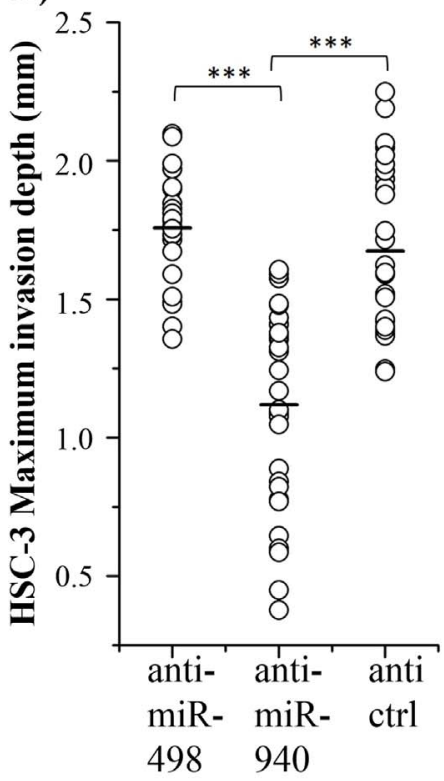

D)

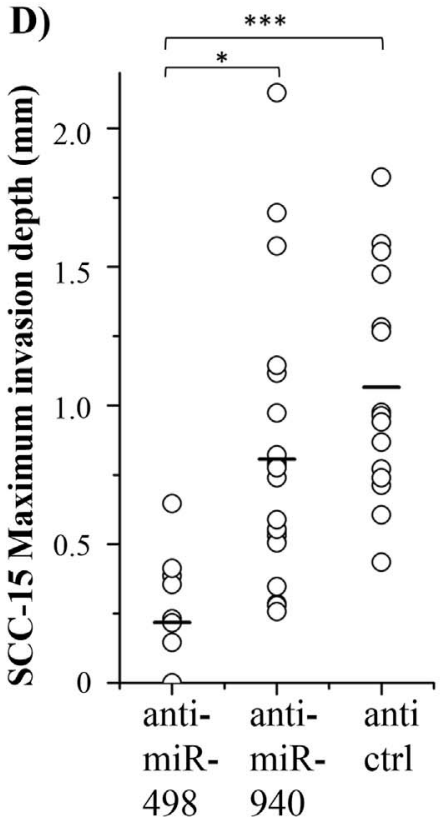

B)

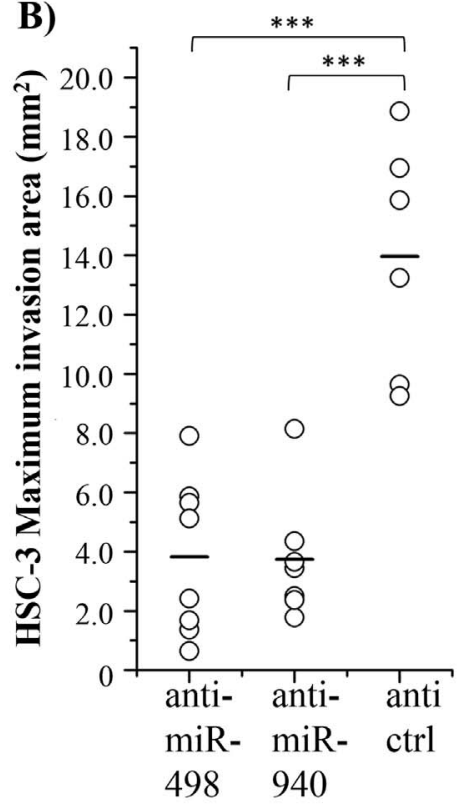

E)

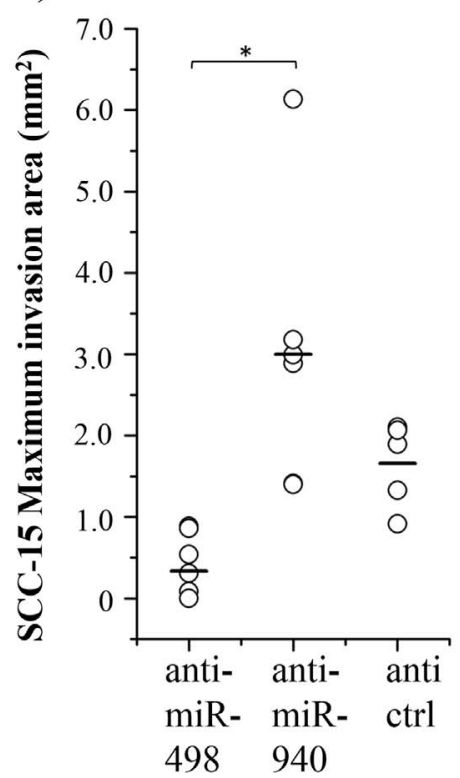

C)

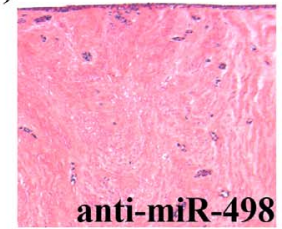

anti-miR-498
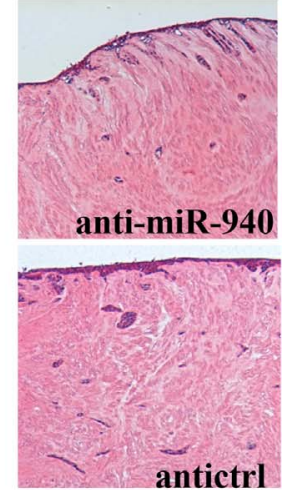

F)

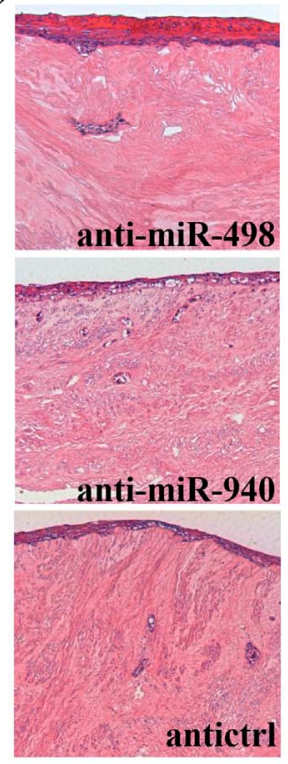

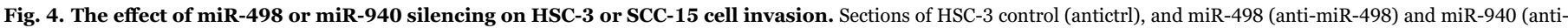

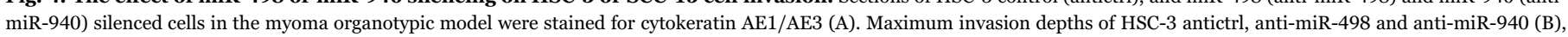

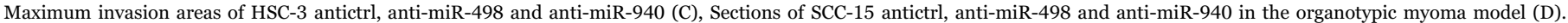

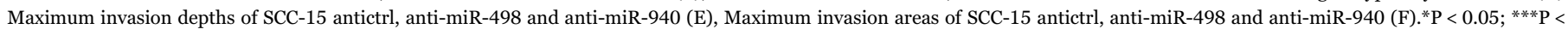
0.001 .

proteins for miR-498 and miR-940, and to discover the particular molecular mechanisms behind their effects. In fact, disturbed miRNA expression may be caused by structural genetic alterations (chromosomal abnormalities, mutations or single nucleotide polymorphisms) either in miRNA coding sequences or in the genes transcribing for the components that participate in miRNA biogenesis [22,55,62]. Disruptions in epigenetic regulation (DNA methylation/hypomethylation) or regulators (other miRNAs or transcription factors) may also explain abnormalities in miRNA expressions in cancerous processes $[22,55,62]$.

Based on the bioinformatic results, and because miR-940 silencing had more extensive effects in vitro than miR-498 silencing, the interaction between miR-940 and CAPG was further explored. CAPG was a favorable candidate, for it has a role in actin filament reorganization and cell movement. Recently, CAPG has also shown promise as a potential biomarker for breast cancer [9] and breast cancer metastasis in bone [60]. CAPG silencing by siRNA was shown to decrease proliferation, invasiveness and metastasis of a prostate cancer cell line DU 145 [30], and CAPG has been implicated also in ovarian cancer migration and/or invasion $[11,12,66]$. However, our current in vitro results indicated that, miR-940 does not regulate CAPG expression in HSC-3 cells invasion or migration in the present study set-ups and under these circumstances. Hence, further research is fundamental in establishing the function of both candidate miRNAs by elucidating the molecular mechanisms behind their effects and to deepen the understanding of miRNAs' effects via very necessary in vivo research.

The miRNAs are redundant and pleiotropic nature of miRNAs should also be remembered when interpreting results. One miRNA may regulate the expression of many target genes and hence different biological processes [1]. Concurrently, a gene may be regulated 
synergistically by several miRNAs [1], and in pathological processes the function of more than one miRNA may be disrupted and/or involved. The great number of regulators and complexity of their interrelations is emphasized in our HSC-3 invasion network results. Furthermore miRNA results are not readily generalized, for miRNA expressions and their effects may be cell or tissue specific or tumor microenvironment dependent $[1,55]$. All of these factors contribute to the intricacy of cancer development and invasion. Finally, it is important to verify the miRNA functional and phenotypic effects in vivo in an appropriate genetic model system. These subjects are to be addressed and pursued in detail in later research. The focus will be in elucidating miRNAs' function and producing consistent in vivo evidence for miRNAs' role in OTSCC in model organism and in patient material. These results will further promote assessing and establishing the significance and feasibility of the two miRNAs in potential future clinical applications such as diagnostics, prognostics and treatment.

Taken together, the pathway enrichment analyses, based on the miRNAs and proteins, annotated "Focal adhesion", "ECM-receptor interaction" and "Regulation of actin cytoskeleton" processes to be involved in the HSC-3 invasion in vitro. Focal adhesions, which bring together actin cytoskeleton and extracellular matrix (ECM) components, potentiate ECM-receptor related interactions by participating e.g. in cell attachment, motility and migration $[13,29,40]$. Those elements are all essential in cancer invasion. Furthermore, we observed that at least miR-498 and -940 have a putative role in 3D invasion by both more and less aggressive OTSCC cells. Yet, additional research is necessary to establish and understand the miR-498 and miR-940 functions and related molecular mechanisms involved in OTSCC invasion. From the future perspective, identifying pathways and various regulatocrs of oral cancer invasion is important for developing targeted therapies against aggressive oral carcinomas, including OTSCC.

\section{Acknowledgements}

Mrs. Maija-Leena Lehtonen and Mrs. Eeva-Maija Kiljander are acknowledged for their excellent technical help in the experiments. We thank the Biocenter Oulu Virus Core laboratory for providing the facilities for the lentiviral silencing. DDS Ahmed MA Al-Samadi and DDS Fabricio Passador-Santos are acknowledged for their valuable comments on the manuscript. This study was supported by the Finnish Cancer Society (TS, IL, KJ), The Sigrid Juselius Foundation (TS), Oulu University Hospital MRC and VTR funding (TS), The Finska Läkaresällskapet foundation (IL, KJ), The Maritza and Reino Salonen Foundation (IL, KJ), and the Turku University Hospital VTR funding (RG). JK was supported by the Finnish Cultural Foundation, the Thelma Mäkikyrö Foundation and Science without borders (CAPES, Brazil). AFPL was supported by FAPESP (2009/54067-3 and 2010/ 19278-0) and CNPq grants (470268/2013-1). RDC was supported by Science without borders (CAPES, Brazil), Coordenação de Aperfeiçoamento de Pessoal de Nível Superior-CAPES, Brasília, Brazil (AUXPE-PVES-570/2013) and Fundação de Amparo a Pesquisa do Estado de São Paulo-FAPESP, São Paulo, Brazil (2013/01607-6). The authors declare no potential conflicts of interest with respect to the authorship and/or publication of this article.

\section{Appendix A. Supporting information}

Supplementary data associated with this article can be found in the online version at doi:10.1016/j.yexcr.2016.10.015.

\section{References}

[1] M. Alečković, Y. Kang, Regulation of cancer metastasis by cell-free miRNAs, Biochim. Biophys. Acta 1855 (2015) 24-42.

[2] A.Z.B. Aragão, M.L.C. Nogueira, D.C. Granato, F.M. Simabuco, R.V. Honorato,
Z. Hoffman, S. Yokoo, F.R. Laurindo, F.M. Squina, A.C. Zeri, et al., Identification of novel interaction between ADAM17 (a disintegrin and metalloproteinase 17) and Thioredoxin-1, JBC 287 (51) (2012) 43071-43082. http://dx.doi.org/10.1074/ jbc.M112.364513.

[3] R. Bhajun, L. Guyon, A. Pitaval, E. Sulpice, S. Combe, P. Obeid, V. Haguet, I. Ghorbel, C. Lajaunie, X. Gidrol, A statistically inferred microRNA network identifies breast cancer target miR-940 as an actin cytoskeleton regulator, Sci. Rep. 5 (2015) 8336. http://dx.doi.org/10.1038/srep08336.

[4] A. Bhat, A. Heinzel, B. Mayer, P. Perco, I. Mühlberger, H. Husi, A.S. Merseburger, J. Zoidakis, A. Vlahou, J.P. Schanstra, et al., Protein interactome of muscle invasive bladder cancer, PLos One 10 (1) (2015) e0116404. http://dx.doi.org/10.1371/ journal.pone.0116404.

[5] M.F. Carazzolle, L.M. de Carvalho, H.H. Slepicka, R.O. Vidal, G.A. Pereira, J. Kobarg, G.V. Meirelles, IIS - Integrated Interactome System: a web-based platform for the annotation, analysis and visualization of protein-metabolite-genedrug interactions by integrating a variety of data sources and tools, PLoS One 9 (6) (2014) e100385. http://dx.doi.org/10.1371/journal.pone.0116404.

[6] W.X. Chen, Z.G. Zhang, Z.Y. Ding, H.F. Liang, J. Song, X.L. Tan, J.J. Wu, G.Z. Li, Z. Zeng, B.X. Zhang, X.P. Chen, MicroRNA-630 suppresses tumor metastasis through the TGF- $\beta$-miR-630-Slug signaling pathway and correlates inversely with poor prognosis in hepatocellular carcinoma, Oncotarget 7 (16) (2016) 22674-22686. http://dx.doi.org/10.18632/oncotarget.8047.

[7] J. Cong, R. Liu, X. Wang, H. Wang, J. Hou, Low miR-498 expression levels are associated with poor prognosis in ovarian cancer, Eur. Rev. Med. Pharm. Sci. 19 (24) (2015) 4762-4765.

[8] J. Cox, N. Neuhauser, A. Michalski, R.A. Scheltema, J.V. Olsen, M. Mann, Andromeda: a peptide search engine integrated into the MaxQuant environment, J. Proteome Res. 10 (4) (2011) 1794-17805. http://dx.doi.org/10.1021/pr101065j.

[9] G.G. Da Costa, T.H. Gomig, R. Kaviski, K. Santos Sousa, C. Kukolj, R.S. De Lima, C. De Andrade Urban, I.J. Cavalli, E.M. Ribeiro, Comparative proteomics of tumor and paired normal breast tissue highlights potential biomarkers in breast, Cancer Genom. Proteom. 12 (5) (2015) 251-261.

[10] P. Friedl, J. Locker, E. Sahai, J.E. Segall, Classifying collective cancer cell invasion, Nat. Cell Biol. 14 (2012) 777-783. http://dx.doi.org/10.1038/ncb2548.

[11] D.M. Gau, J.L. Lesnock, B.L. Hood, R. Bhargava, M. Sun, K. Darcy, S. Luthra, U. Chandran, T.P. Conrads, R.P. Edwards, J.L. Kelley, T.C. Krivak, P. Roy, BRCA1 deficiency in ovarian cancer is associated with alteration in expression of several key regulators of cell motility - a proteomics study, Cell Cycle 14 (12) (2015) 1884-1892. http://dx.doi.org/10.1080/15384101.2015.1036203.

[12] J. Glaser, M.H. Neumann, Q. Mei, B. Betz, N. Seier, I. Beyer, T. Fehm, H. Neubauer, D. Niederacher, M.C. Fleisch, Macrophage capping protein CapG is a putative oncogene involved in migration and invasiveness in ovarian carcinoma, Biomed. Res. Int. 2014 (2014) 379847. http://dx.doi.org/10.1155/2014/379847.

[13] M.L. Gardel, I.C. Schneider, Y. Aratynn-Schaus, C.M. Waterman, Mechanical integration of actin and adhesion dynamics in cell migration, Annu. Rev. Cell Dev. Biol. 26 (2010) 315-333. http://dx.doi.org/10.1146/annurev.cellbio.011209.122036.

[14] V. Gopalan, R.A. Smith, Lam AK-Y, Downregulation of microRNA-498 in colorectal cancers and its cellular effects, Exp. Cell Res. 330 (2) (2015) 423-428. http:// dx.doi.org/10.1016/j.yexcr.2014.08.006.

[15] R.I. Haddad, D.M. Shin, Recent advances in head and neck cancer, N. Engl. J. Med. 359 (2008) 1143-1154. http://dx.doi.org/10.1056/NEJMra0707975.

[16] E. Hadler-Olsen, P. Kanapathippillai, E. Berg, G. Svineng, J.O. Winberg, L. UhlinHansen, Gelatin in situ zymography on fixed, paraffin-embedded tissue: zinc and ethanol fixation preserve enzyme activity, J. Histochem. Cytochem. 58 (2010) 29-39. http://dx.doi.org/10.1369/jhc.2009.954354.

[17] D. Hanahan, R.A. Weinberg, Hallmarks of cancer: the next generation, Cell (5) (2011) 646-674. http://dx.doi.org/10.1016/j.cell.2011.02.013.

[18] C. Hebert, K. Norris, M.A. Scheper, N. Nikitakis, J.J. Sauk, High mobility group A2 is a target for miRNA-98 in head and neck squamous cell carcinoma, Mol. Cancer 6 (2007) 5. http://dx.doi.org/10.1186/1476-4598-6-5.

[19] C.S. Ho, S.H. Yap, N.H. Phuah, L.L. In, N. Hasima, MicroRNAs associated with tumour migration, invasion and angiogenic properties in A549 and SK-Lu1 human lung adenocarcinoma cells, Lung Cancer 83 (2014) 154-162. http://dx.doi.org/ 10.1016/j.lungcan.2013.11.024.

[20] N.C. Hubner, A.W. Bird, J. Cox, B. Splettstoesser, P. Bandilla, I. Poser, A. Hyman, M. Mann, Quantitative proteomics combined with BAC TransgeneOmics reveals in vivo protein interactions, J. Cell Biol. 189 (4) (2010) 739-754. http://dx.doi.org/ 10.1083/jcb.200911091.

[21] R.C. Inglehart, C.S. Scanlon, N.J. D’Silva, Reviewing and reconsidering invasion assays in head and neck cancer, Oral. Oncol. 50 (12) (2014) 1137-1143. http:// dx.doi.org/10.1016/j.oraloncology.2014.09.010.

[22] M.V. Iorio, C.M. Croce, MicroRNA involvement in human cancer, Carcinogenesis 33 (6) (2012) 1126-1233. http://dx.doi.org/10.1093/carcin/bgs140.

[23] S. Irani, MiRNAs signature in head and neck squamous cell carcinoma metastasis: A literature review, J. Dent. Shiraz. Univ. Med. Sci. 17 (2) (2016) 71-83.

[24] R. Kasiappan, Z. Shen, A.K.-W. Tse, U. Jinwal, J. Tang, P. Lungchukiet, Y. Sun, P. Kruk, S.V. Nicosia, X. Zhang, et al., 1,25-Dihydroxyvitamin D3 suppresses telomerase expression and human cancer growth through MicroRNA-498, J. Biol. Chem. 287 (2012) 41297-41309. http://dx.doi.org/10.1074/jbc.M112.407189.

[25] R. Kasiappan, Y. Sun, P. Lungchukiet, W. Quarni, X. Zhang, W. Bai, Vitamin D suppresses leptin stimulation of cancer growth through microRNA, Cancer Res. 74 (2014) 6194-6204. http://dx.doi.org/10.1158/0008-5472.CAN-14-1702.

[26] R. Kawahara, R.N. Lima, R.R. Domingues, B.A. Pauletti, G.V. Meirelles, M. Assis, A.C. Figueira, A.F. Paes Leme, Deciphering the role of the ADAM17-dependent secretome in cell signaling, J. Proteome Res. 13 (4) (2014) 2080-2093. http:// 
dx.doi.org/10.1021/pr401224u.

[27] N. Kramer, A. Walzl, C. Unger, M. Rosner, G. Krupitza, M. Hengstschläger, H. Dolznig, In vitro cell migration and invasion assays, Mutat. Res. 752 (2013) 10-24. http://dx.doi.org/10.1016/j.mrrev.2012.08.001.

[28] S.-K. Leivonen, K.K. Sahlberg, R. Mäkelä, E.U. Due, O. Kallioniemi, A.L. BørresenDale, M. Perälä, High-throughput screens identify microRNAs essential for HER2 positive breast cancer growth, Mol. Oncol. 8 (1) (2014) 93-104. http://dx.doi.org/ 10.1016/j.molonc.2013.10.001.

[29] R.E. Leube, M. Moch, R. Windoffer, Intermediate filaments and the regulation of focal adhesion, Curr. Opin. Cell Biol. 32 (2015) 13-20. http://dx.doi.org/10.1016/ j.ceb.2014.09.011.

[30] B.K. Li, K. Guo, C.Y. Li, H.L. Li, P.P. Zhao, K. Chen, C.X. Liu, Influence of suppression of CapG fene expression by siRNA on the growth and metastasis of human prostate cancer cells, Genet Mol. Res. 14 (4) (2015) 15769-15778. http:// dx.doi.org/10.4238/2015.December.1.28.

[31] C.C. Liang, A.Y. Park, J.L. Guan, In vitro scratch assay: a convenient and inexpensive method for analysis of cell migration in vitro, Nat. Protoc. 2 (2) (2007) 329-333. http://dx.doi.org/10.1038/nprot.2007.30.

[32] R. Liu, F. Liu, L. Li, M. Sun, K. Chen, MiR-498 regulated FOXO3 expression and inhibited the proliferation of human ovarian cancer cells, Biomed. Pharm. 72 (2015) 52-57. http://dx.doi.org/10.1016/j.biopha.2015.04.005.

[33] X. Liu, X. Ge, Z. Zhang, X. Zhang, J. Chang, Z. Wu, W. Tang, L. Gan, M. Sun, J. Li, MicroRNA-940 promotes tumor cell invasion and metastasis by downregulating ZNF24 in gastric cancer, Oncotarget 6 (28) (2015) 25418-25428.

[34] X. Liu, A. Kwong, A. Sihoe, K.M. Chu, Plasma miR-940 may serve as a novel biomarker for gastric cancer, Tumour Biol. 37 (3) (2015) 3589-3597.

[35] K.J. Livak, T.D. Schmittgen, Analysis of relative gene expression data using realtime quantitative PCR and the $2_{\mathrm{T}}^{-\Delta \mathrm{C}}$ method, Methods 25 (4) (2001) 402-408. http://dx.doi.org/10.1006/meth.2001.1262.

[36] J. Ma, F. Sun, C. Li, Y. Zhang, W. Xiao, Z. Li, Q. Pan, H. Zeng, G. Xiao, K. Yao, et al., Depletion of intermediate filament protein Nestin, a target of microRNA-940, suppresses tumorigenesis by inducing spontaneous DNA damage accumulation in human nasopharyngeal carcinoma, Cell Death Dis. 5 (2014) e1377. http:// dx.doi.org/10.1038/cddis.2014.293.

[37] N. Matamala, M.T. Vargas, R. González-Cámpora, J.I. Arias, P. Menéndez, E. Andrés-León, K. Yanowsky, A. Llaneza-Folgueras, R. Miñambres, B. MartínezDelgado, J. Benítez, MicroRNA deregulation in triple negative breast cancer reveals a role of miR-498 in regulating BRCA1 expression, Oncotarget 7 (15) (2016) 20068-20079. http://dx.doi.org/10.18632/oncotarget.7705.

[38] A. Min, C. Zhu, S. Peng, S. Rajthala, D.E. Costea, D. Sapkota, MicroRNAs as important players and biomarkers in oral carcinogenesis, BioMed Res. Int. (2015). http://dx.doi.org/10.1155/2015/186904 Article ID 186904.

[39] S. Nurmenniemi, T. Sinikumpu, I. Alahuhta, S. Salo, M. Sutinen, M. Santala, J. Risteli, P. Nyberg, T. Salo, A novel organotypic model mimics the tumor microenvironment, Am. J. Pathol. 175 (2009) 1281-1291. http://dx.doi.org/ 10.2353/ajpath.2009.081110.

[40] J.T. Parsons, A.R. Horwitz, M.A. Schwartz, Cell adhesion: integrating cytoskeletal dynamics and cellular tension, Nat. Rev. Mol. Cell Biol. 11 (2010) 633-643. http:// dx.doi.org/10.1038/nrm2957.

[41] W.J. Polacheck, I.K. Zervantonakis, R.D. Kamm, Tumor cell migration in complex microenvironments, Cell Mole. Life Sci. Apr. 70 (8) (2013) 1335-1356. http:// dx.doi.org/10.1007/s00018-012-1115-1.

[42] G.M. Polachini, L.M. Sobral, A.M.C. Mercante, A.F. Paes-Leme, F.C. Xavier, T. Henrique, D.M. Gimarães, A. Vidotto, E.E. Fukuyama, J.F. Góis-Filho, et al., Proteomic approaches identify members of Cofilin pathway involved in oral tumorigenesis, PLoS One 7 (12) (2012) e50517. http://dx.doi.org/10.1371/journal.pone.0050517.

[43] S. Rajendiran, A.V. Parwani, R.J. Hare, S. Dasgupta, R.K. Roby, J.K. Vishwanatha, MicroRNA-940 suppresses prostate cancer migration and invasion by regulating MIEN1, Mol. Cancer 13 (2014) 250. http://dx.doi.org/10.1186/1476-4598-13250.

[44] J. Rappsilber, M. Mann, Y. Ishihama, Protocol for micro-purification, enrichment, pre-fractionation and storage of peptides for proteomics using StageTips, Nat. Protoc. 2 (8) (2007) 1896-1906. http://dx.doi.org/10.1038/nprot.2007.261.

[45] J.G. Rheinwald, M.A. Beckett, Defective terminal differentiation in culture as a consistent and selectable character of malignant human keratinocytes, Cell 22 (1980) 629-632. http://dx.doi.org/10.1016/0092-8674(80)90373-6.

[46] M.R. Sajnani, A.K. Patel, V.D. Bhatt, A.K. Tripathi, V.B. Ahir, V. Shankar, S. Shah, T.M. Shah, P.G. Koringa, S.J. Jakhesata, et al., Identification of novel transcripts deregulated in buccal cancer by RNA-seq, Gene 507 (2) (2012) 152-158. http:// dx.doi.org/10.1016/j.gene.2012.07.036.

[47] T. Salo, M. Sutinen, E. Hoque Apu, E. Sundquist, N.K. Cervigne, C.E. de Oliveira, S.U. Akram, S. Ohlmeier, F. Suomi, L. Eklund, et al., A novel human leiomyoma tissue derived matrix for cell culture studies, BMC Cancer Dec. 15 (2015) 981. http://dx.doi.org/10.1186/s12885-015-1944-z Dec 16.

[48] L. Santarpia, G.A. Caln, L. Adam, L. Ye, A. Fusco, S. Giunti, C. Thaller, L. Paladini, $\mathrm{X}$. Zhang, C. Jimenez, et al., A miRNA signature associated with human metastatic medullary thyroid carcinoma, Endocr.-Relat. Cancer 20 (2013) 809-823. http:// dx.doi.org/10.1530/ERC-13-0357.

[49] T. Schepeler, J.T. Reinert, L.L. Ostenfeld, L.L. Christensen, A.N. Silahtaroglu, L. Dyrskjøt, C. Wiuf, F.J. Sørensen, M. Kruhøffer, S. Laurberg, et al., Diagnostic and prognostic microRNAs in stage II colon cancer, Cancer Res. 68 (2008) 6416-6424. http://dx.doi.org/10.1158/0008-5472.CAN-07-6110.

[50] P. Shannon, A. Markiel, O. Ozier, N.S. Baliga, J.T. Wang, D. Ramage, N. Amin B. Schwikowski, T. Ideker, Cytoscape: a software environment for integrated models of biomolecular interaction networks, Genome Res 13 (2003) 2498-2504. http://dx.doi.org/10.1101/gr.1239303.

[51] Z.L. Shen, B. Wang, K.W. Jiang, C.X. Ye, C. Cheng, Y.C. Yan, J.Z. Zhang, Y. Yang, Z.D. Gao, Y.J. Ye, S. Wang, Downregulation of miR-199b is associated with distant metastasis in colorectal cancer via activation of SIRT1 and inhibition of CREB/ KISS1 signaling, Oncotarget (2016). http://dx.doi.org/10.18632/oncotarget.9042 (Apr 27. Epub ahead of print).

[52] M. Smoot, K. Ono, J. Ruscheinski, P.L. Wang, T. Ideker, Cytoscape 2.8: new features for data integration and network visualization: Bioinformatics visualization, Bioinformatics 27 (2011) 431-432. http://dx.doi.org/10.1093/bioinformatics/btq675.

[53] D. Spano, C. Heck, P. De Antonellis, G. Christofori, M. Zollo, Molecular networks that regulate cancer metastasis, Semin. Cancer Biol. 22 (2012) 234-249. http:// dx.doi.org/10.1016/j.semcancer.2012.03.006.

[54] B. Song, C. Zhang, G. Li, G. Jin, C. Liu, MiR-940 inhibited pancreatic ductal adenocarcinoma growth by targeting MyD88, Cell Physiol. Biochem. 35 (3) (2015) 1167-1177. http://dx.doi.org/10.1159/000373941.

[55] H.I. Suzuki, A. Katsura, H. Matsuyama, K. Miyazono, MicroRNA regulons in tumor microenvironment, Oncogene 34 (2015) 3085-3094. http://dx.doi.org/10.1038/ onc.2014.254.

[56] E. Van Schooneveld, H. Wildiers, I. Vergote, P.B. Vermeulen, L.Y. Dirix, S.J. Van Laere, Dysregulation of microRNAs in breast cancer and their potential role as prognostic and predictive biomarkers in patient management, Breast Cancer Res. 17 (2015) 21. http://dx.doi.org/10.1186/s13058-015-0526-y.

[57] S. Vasudevan, Y. Tong, J.A. Steitz, Switching from repression to activation: micrornas can up-regulate translation, Science 318 (5858) (2007) 1931-1934. http://dx.doi.org/10.1126/science.1149460 (December 21).

[58] I.S. Vlachos, T. Kostoulas, G. Vergoulis, G. Georgakilas, M. Reczko, M. Maragkakis, M.D. Paraskevopoulou, K. Prionidis, T. Dalamagas, A.G. Hatzigeorgiou, DIANA miRPath v.2.0: investigating the combinatorial effect of microRNAs in pathways, Nucleic Acids Res. (2012) W498-W504. http://dx.doi.org/10.1093/nar/gks494.

[59] M. Wang, Q. Zhang, J. Wang, Y. Zhai, MicroRNA-498 is downregulated in nonsmall cell lung cancer and correlates with tumor progression, J. Cancer Res Ther. 1 (Suppl) (2015) C107-C111. http://dx.doi.org/10.4103/0973-1482.163859.

[60] J.A. Westbrook, D.A. Cairns, J. Peng, V. Speirs, A.M. Hanby, I. Holen, S.L. Wood, P.D. Ottewell, H. Marshall, R.E. Banks, P.J. Selby, R.E. Coleman, J.E. Brown, CAPG and GIPC: breast cancer biomarkers for bone metastasis development and treatment, J. Natl. Cancer Inst. 108 (4) (2016) djv360. http://dx.doi.org/10.1093/ jnci/djv360.

[61] E.A.C. Wiemer, The role of microRNAs in cancer: no small matter, Eur. J. Cancer 43 (10) (2007) 1529-1544. http://dx.doi.org/10.1016/j.ejca.2007.04.002.

[62] B.-h. Wu, X.-p. Xiong, J. Jia, W.-f. Zhang, MicroRNAs: new actors in the oral cancer scene, Oral. Oncol. 47 (2011) 314-319. http://dx.doi.org/10.1016/j.oraloncology.2011.03.019.

[63] H. Xiao, A. Langerman, Y. Zhang, O. Khalid, S. Hu, C.X. Cao, M.W. Lingen, D.T.W. Wong, Quantitative proteomic analysis of microdissected oral epithelium for cancer biomarker discovery, Oral. Oncol. 51 (2015) 1011-1019. http:// dx.doi.org/10.1016/j.oraloncology.2015.08.008.

[64] H.W. Yang, G.H. Liu, Y.Q. Liu, H.C. Zhao, Z. Yang, C.L. Zhao, X.F. Zhang, H. Ye, Over-expression of microRNA-940 promotes cell proliferation by targeting GSK3 $\beta$ and sFRP1 in human pancreatic carcinoma, Biomed. Pharm. 83 (2015) 593-601. http://dx.doi.org/10.1016/j.biopha.2016.06.057.

[65] B. Yuan, Y. Liang, D. Wang, F. Luo, MiR-940 inhibits hepatocellular carcinoma growth and correlates with prognosis of hepatocellular carcinoma patients, Cancer Acids. 106 (7) (2015) 819-824. http://dx.doi.org/10.1111/cas.12688.

[66] F. Zhang, C. Li, H. Liu, Y. Wang, Y. Chen, X. Wu, The functional proteomics analysis of VEGF-treated human epithelial ovarian cancer cells, Tumour Biol. 35 (12) (2014) 12379-12387. http://dx.doi.org/10.1007/s13277-014-2552-2.

[67] J.-J. Zhao, J. Yang, J. Lin, N. Yao, Y. Zhu, J. Zheng, J. Xu, J.Q. Cheng, J.Y. Lin, $\mathrm{X}$. Ma, Identification of miRNAs associated with tumorigenesis of retinoblastoma by miRNA microarray analysis, Childs Nerv. Syst. 25 (2009) 13-20. http:// dx.doi.org/10.1007/s00381-008-0701-x. 